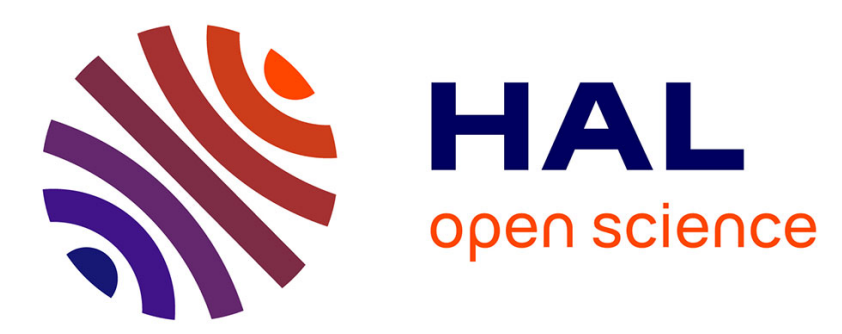

\title{
Occurrence of cytochrome P450 mono-oxygenases in the metabolism of chlorotoluron by wheat microsomes
}

\author{
Christian Mougin, René Scalla, F. Cabanne
}

\section{To cite this version:}

Christian Mougin, René Scalla, F. Cabanne. Occurrence of cytochrome P450 mono-oxygenases in the metabolism of chlorotoluron by wheat microsomes. Herbicide Resistance in Weeds and Crops, 1991, ISBN: 978-0-7506-1101-5. 10.1016/B978-0-7506-1101-5.50054-1 . hal-01600102

\section{HAL Id: hal-01600102 \\ https://hal.science/hal-01600102}

Submitted on 7 Jun 2020

HAL is a multi-disciplinary open access archive for the deposit and dissemination of scientific research documents, whether they are published or not. The documents may come from teaching and research institutions in France or abroad, or from public or private research centers.
L'archive ouverte pluridisciplinaire HAL, est destinée au dépôt et à la diffusion de documents scientifiques de niveau recherche, publiés ou non, émanant des établissements d'enseignement et de recherche français ou étrangers, des laboratoires publics ou privés. 


\title{
OCCURRENCB OF CTTOCHROKB $\mathbf{P}_{450}$ MONO-0XYGENASBS IN THB METABOLISH OP CHLOROTOLURON BY UHRAT MICROSOIRS
}

\author{
C. Mougin, R. Scalla and F. Cabanne \\ Laboratoire des Herbicides (INRA), BV 1540, 20134 Dijon Cedex, France
}

Wheat cell suspension cultures metabolise the herbicide chlorotoluron by ring-methyl hydroxylation, $\mathrm{N}$-demethylation and sugar conjugation (Cole and Owen, 1987; Canivenc etal., 1989). Cell suspension cultures were used to study oxidative transformation of chlorotoluron in vitro. Achlorophyllous cells of wheat cv. Koga II were cultivated as previously described (Canivenc et al., 1989). Microsomes were isolated by differential centrifugation from cells treated with cyometrinil.

Aerobic incubations of microsomes with chlorotoluron and NADPH led to the formation of ring-methyl hydroxylated and N-monodemethylated chlorotoluron. Metabolites were analysed in subcellular fractions after differential centrifugation. They were mainly found in the microsomal fraction in mixture with NADPH-cytochrome $P_{450}$ (cytochrome c) reductase activity. Microsomes metabolised the herbicide at rates ranging from 600 to 650 and 200 to 250 pmoles $\mathrm{mg}^{-1} 30 \mathrm{~min}^{-1}$ for the ring-methyl hydroxylase and N-demethylase, respectively. Microsomal pellets contained substantial levels of cytochrome $\mathrm{P}_{450}$ (300 pmol mg protein ${ }^{-1}$ ).

In cells grown in the presence of cyometrinil, chlorotoluron ring-methyl hydroxylase, $\mathrm{N}$-demethylase, and lauric acid hydroxylase activities were stimulated respectively 1.6-,3.3- and 1.4-fold compared to controls. The cytochrome $P_{450}$ content of microsomes was increased 1.8 -fold by cyometrinil. Ring-methyl hydroxylase and $\mathrm{N}$-demethylase activities exhibited their highest rates with NADPH. Other reductants such as NADH, dithionite or ascorbate were ineffective. Molecular oxygen was also necessary for the NADPH-dependent activities. Herbicide hydroxylase and $\mathrm{N}$-demethylase were drastically reduced by inhibitors of the $\mathrm{P}_{450}$ system, namely $\mathrm{ABT}, \mathrm{p}$-CMB, menadione and cytochrome $c$.

Carbon monoxide (CO) inhibited the hydroxylase activity with partial reversion by light. In contrast, $\mathrm{N}$-demethylase activity was apparently insensitive to $\mathrm{CO}$. Only the monodemethylated metabolite could also be formed in the presence of cumene hydroperoxide as oxygen donor.

These data allow us to postulate that chlorotoluron ring-methyl hydroxylase and $\mathrm{N}$-demethylase activities probably belong to the family of cytochrome $\mathrm{P}_{450}$ mono-oxygenases. The fact that the N-demethylation can consume cumene hydroperoxide leads to a possible role of another type of mono-oxygenase, for example a peroxygenase-type enzyme, in addition to cytochrome $P_{450}$. 